\title{
INDIVIDUAL APPROACHES TO THE CREATION OF ARTWORK IN PRIMARY SCHOOL STUDENTS
}

\author{
Matjaž Duh, PhD \\ Faculty of Education, University of Maribor (Slovenia) \\ e-mail: matjaz.duh@uni-mb.si \\ Aleksandra Slatinšek-Mlakar, BA \\ e-mail: sandrasm8@gmail.com
}

\begin{abstract}
A b stract
The article discusses a research which monitored the process of drawing the human figure in nine year olds. A case study was used to examine artwork produced by three girls. A qualitative research was conducted to establish the process of drawing the human figure on the basis of video recordings, photographs and answers provided in worksheets. The obtained findings confirm the assumption that students choose their own individual approach to constructing artwork.

Key words: drawing, development phases, process of drawing, human figure
\end{abstract}

\section{Introduction}

A child's early artwork represents the most general comprehension of the world and life, i.e. what the child understands or tries to clarify to himself. A child's drawing goes through constant developmental phases, from the simplest scribbles to highly evolved schemes. A child will use his drawing for creative expression when he feels free and safe. He will be artistically creative when he knows that his product and his perceptions are accepted. He therefore needs to be provided an opportunity to acquire appropriate creative experiences using different materials giving him the possibility of diverse expression. In early childhood, this is the task of the parents and later of institutional education. Modern arts education and its creative and productive dimension need to motivate students to search for design and expression possibilities and to implement their perceptions and impressions by helping them work through clarify and understand their truth of life. "Not only the clarification and processing of reality but also the constructive, meaningful and re-formulated meaning-bearing symbols are the aims of arts education" (Kircher et. al., 2006:13). 
Students need to be motivated to develop their expressive abilities and expand them to symbolic expression.

Artistic expression of younger children shows itself in the role of a child's cognitive development and represents an aid that the child uses to come to know, explore and work out the world around him. While adults are able to handle the reality surrounding us in different ways, a child does not have such possibilities and experiences. He therefore explores his world with movements and other senses and through drawing. Children thus draw in order to fulfil their need for movement and for the pleasure arising from leaving a trail, getting to know and arrange spatial relations and new meanings that they are gradually able to shape. The drawing acts as a mediator between the inner world of thoughts and the outer world of objects. Muhovič (1999) notes that the cognitive aspect of drawing can also be explained differently: we probably do not understand what we are unable to draw. From the psychological point of view, we speak of characteristics of development that always follow certain consistent rules, developmental sequences or models.

As children are growing up, their drawings become more proportionate and more realistic and include a growing number of elements and details. In this context, it needs to be said that analyses of drawings made by children of different age groups indicate certain developmental characteristics that determine different developmental stages of a child's artistic expression (Thomas and Silk, 1990; as referenced by Marjanovič Umek and Lešnik Musek, 2001). A child's drawing is gradually transformed from objective depiction into pictorial forms, a direction that leads from objects to images. It is not to be neglected, as Schrader notes, that a "child draws, not what he sees, but uses the drawing to bring about interesting, pleasant or exciting situations that he wishes to re-experience" (Schrader, 2000: 234). The non-verbal nature of drawings gives the child the freedom to express emotions and behaviours that would otherwise be difficult to evaluate. In his drawing, the child is able to depict his conscious and unconscious behaviour, desires, needs and conflicts. The drawing expresses the child's internal working model of relationships (Fury, Carlson and Sroufe, 1997; as referenced by Cugmas, 2003).

As regards the visual and thematic development of artistic expression, which mainly coincides with a child's intellectual development, there are four main developmental phases: the scribbling phase, the symbols phase, the shapes and phenomena phase and the phase of comprehensive artistic expression. The criteria of developmental characteristics or changes are the depiction of figure and movement and of objects and space. The fastest progress is seen in drawing the human figure followed by objects and movement, while space depiction takes the longest to develop, somewhere till the age of 14 (Karlavaris, 1991a).

The scribbling phase begins in early childhood and lasts to the age of four. The child's scribbles, which do not depict anything special, are different: vertical and horizontal, circular and combined lines. The symbols phase begins at around age four and lasts to about age seven. The child already uses different oval, square or spiral shapes in his drawings. His main interest, which he wishes to depict, is the 
human figure. The child starts with drawing a circle and then draws tadpoles. Later, this symbol is divided into the head, trunk and finally the neck (Marjanovič Umek and Lešnik Musek, 2001, Schrader, 2000, Karlavaris, 1991a, Grgurić and Jakubin, 1996). Around the age of seven, the child is able to understand adult instructions. In this phase, he increasingly thinks about his drawing and its accuracy and still enjoys the game and is relaxed. The children develop the depiction of figures, motion, sizes and space in accordance with the developmental stages of all children (Duh and Vrlič 2003, Tanay, 1988). As children reach the age of 7 to 8, they lean towards intellectual realism. They observe objects for a longer time and wish to be realistic in their drawings in order to give a good presentation of the objects. They show more interest in visually more realistic drawings, especially perspective drawings (Cox, 2005). This development evidently continues in depicting figures, where motion is indicated and side view drawings of the human figure emerge. In artistic compositions, extracts are used and children indicate space through overlapping objects. Colour is used as a sign to indicate objects and phenomena and there is a multiplicity of colours used. (Vrlič, 2001). The next phase, the phase of shapes and phenomena, lasts from the age of seven to ten. A typical characteristic of this phase is the increasing accuracy or objectiveness in depicting figures, movement, objects and space. During this period, children's drawings deal with the depiction of depth and not only in drawing individual elements but also in depicting relations between these elements. They draw the object or an activity from a certain perspective. The proportions and relationships between elements are depicted more realistically. The objects no longer stand next to each other. The distant objects are smaller than the nearer objects giving the impression of depth (Horvat and Magajna, 1987; Thomas and Silk, 1990; Golomb, 1992; as referenced by Marjanovič Umek and Lešnik Musek, 2001). The next stage, which lasts from ten to fourteen years of age, is the phase of comprehensive artistic expression, a phase of visual realism "that is characterised by a more realistic depiction of objects" (Grgurić and Jakubin, 1996:73). Drawing is based on a more objective depiction of figures and objects. There are details and a precision of lines and shapes, movement and space are rather clearly indicated. Once a child reaches this stage, his development continues or moves through different versions of artistic design in adolescent years (Karlavaris, 1991a). The child's depiction of the human figure develops through these developmental stages. The proportions become increasingly realistic, the figures are depicted from the front or side and numerous elements are added: palms, feet, eyebrows, eyelashes and other. The lower extremities are the first to be depicted in side view, followed by the upper extremities and it is only later that they are able to depict the entire figure from the side (Marjanovič Umek and Lešnik Musek, 2001). The development of primary school children continues towards a greater objectiveness of artistic expression. An increasing number of visual impressions can be included in arts education. Alongside better motor development, arts education is influenced by more developed intellectual abilities of children and a broader range of their interests (Vrlič, 2001). As Kircher notes, this includes the experience that "artistic creation can take unexpected turns and that there can be both disrupting 
blocks to the creative process as well as surprising and exhilarating success." (Kircher et. al. 2006:15).

Alongside the described characteristics of a child's artistic development there are also deviations that are brought about by environmental impacts and that depend on numerous factors such as for example the social status, tradition, media, impacts of modern art and others. There are individual differences evident in artistic development of children. These are due to uneven development of individual abilities and personal characteristics. The complete set of these impacts is classified as subjective artistic factors (Duh, 2004). Quantitative factors, such as detailed perception, visual memory, imagination and motor skills enable artistic activities, while qualitative factors, such as sensitivity, creative thinking, emotions and sensibility facilitate artistic creation (Duh, 2004; Karlavaris, 1981). Differences among children further depend on different artistic types. Artistic types of children are mainly classified with regard to artistic factors, personal characteristics and affinity to visual means of expression. With regard to the latter, children can be classified into several groups with each characteristic having its antipole (the visual type - the imaginative type, the intellectual type - the expressive type, the sensitive type - the artistic memory type, the analytical type - the synthetic type, the motor and technical type - the unskilful type (Duh, Vrlič, 2003, Karlavaris 1991b).

\section{Qualitative arts education research}

Similarly to social and humanistic sciences, arts education research employs both the quantitative and the qualitative paradigm of scientific educational research (Vogrinec, 2008). "While quantitative research aims to measure the impact of the arts on student learning by testing the claims of its advocates through controlled, experimental methods, qualitative research methods may be applied in an effort to describe the impact of the arts in education within the heuristic world of arts education practice, a world in which random factors tend to impede the effectiveness of experimental design" (O'Farrell, Meban, 2005:155). Often a combination of both approaches is desired in order to establish a comprehensive understanding of arts education and didactics related subject matter.

In qualitative research, researchers are directly included in the environment. As Licthman notes, qualitative research is "a way of knowing in which a researcher gathers, organises, and interprets information obtained from humans using his or her eyes and ears as filters. It often involves in-depth interviews and/or observations of humans in natural and social settings. It can be contrasted with quantitative research, which relies heavily on hypothesis testing, cause and effect and statistical analyses." (Lichtman, 2009:5). These are researches that analyse and deal with the material in a verbal way without using measurement methods that provide numbers and without operating with numbers (Mesec, 1998). Hence research results obtained under the qualitative paradigm cannot be generalised independently of the environment in which they had been obtained. Qualitative scientific educational research focuses more on the processes of educational work and not only on end results. In a 
qualitative research, data is collected through observation (participant or nonparticipant, by recording sound and picture), interviews and discussions, an analysis of students' work, by using an opinions scale, polling and collecting available data (Sagadin, 1991). Qualitative techniques of data collection are less structured. Their advantage lies in the diversity or wealth of obtained data. They include open-ended questionnaires, document analysis, journals (teacher's, student's observer's), nonstandardised interviews, unplanned or random observation, essay type tasks, etc. (Cencič, 2002).

The present study employed qualitative research, as it involves a process of reciprocal clarification of the researcher's concept of the research subject on the one hand and the concepts that frame the investigation on the other. These notions are built up from cases, sometimes by searching for similarities among several examples of the phenomenon that seem to be in the same general category (Ragin, 2007). The main technique of data collection in the presented observational case study is participant observation. In order to monitor art and design strategies of children, i.e. to establish how artwork is constructed, the qualitative approach should be used, as the process of how artwork is made needs to be monitored. The appropriate technique of data collection is a combination of observation and document analysis, i.e. visual material. Sufficiently reliable data for the analysis of art and design strategies of children can be obtained by filming the process and with target-oriented photographing of the studied individuals. Photographs for qualitative research need to be taken in a manner clearly showing the studied elements. "The decision on the angle of view depends on the theoretical assumptions of the researcher and his understanding of the research position. The visual material is analysed in the same manner as text, as photographs also tell a story" (Duh, 2009: 88). Today, photographs play a different role in arts education research. Photographs evolved from their initial illustrative role to being regarded as independent and autonomous research material. Peez notes that "photos are being increasingly used in qualitative empirical researches; usually not as the only research material but as addition to participant observations, transcripts of statements (e.g. interviews) or written reports by students on art or their own artwork." (Peez, 2006:15). If a photograph is used as a research document, the researcher has to verify its authenticity.

\section{Methodology}

The research focused on how a child depicts the human figure (the drawing process) and his attitude towards drawing or depicting a human figure in an individual working stage considering the chosen motif and art technique. The study derived from the assumption that the child employs the same process in drawing a human figure regardless of the chosen theme, technique and material (means). The purpose of the qualitative research was to establish how children depict the human figure, i.e. art and design strategies of children and their attitude towards the motif, i.e. the human figure while employing the art technique of drawing three different themes. The aim of the research was to understand individual art and design processes of children and to consider them in arts education in school. 
Three stages were chosen for the research, each employing the same art motif (the human figure), the same art technique (drawing) and three different themes:

Stage 1 Drawing with pencil - Nature Classes;

Stage 2 Drawing with coloured pencils - Playing in the Playground;

Stage 3 Drawing with charcoal - My Shadow

The research comprised an observational case study with a detailed and systematic analysis of individual students in drawing the human figure during individual working stages with the chosen motif and art technique as well as the attitude of individual students towards drawing. An idiographic approach was employed monitoring the development of individual elements of the studied situation, i.e. art strategies of three children with the same artistic starting points. The descriptive and comparative methods of empirical educational research were employed. The research included three fifth grade students from the OŠ Prežihovega Voranca Ravne na Koroškem primary school. The number of included students is relevant to the research, as it ensures that the required answers to the posed research questions are obtained.

Data were collected by recording the process using a video camera, using photographs and worksheets before and after the implementation of the task. The recordings were used to analyse the process of drawing the human figure, which represents the main source of data for analysing art strategies of students. The photographs of the final products have an illustrative role. The worksheets with questions on the implementation of the task were used to establish the students' attitude towards an individual task as regards the theme, technique and material (means). The drawing was used as an instrument to obtain data. Data reliability was ensured through repetition of the task. The validity of the measurement instrument is ensured, as it corresponds to the findings presented in subject related literature. In the implementation phase, the objectivity of the instrument was ensured by providing unified and unambiguous instructions for the task for all students.

The research verified all four criteria for establishing document quality: authenticity, credibility, meaning and representativeness and established that the chosen photographs fully correspond with all the requirements.

The research was conducted in three stages. Before each stage, students were given uniform instructions on what to draw and questions on current knowledge regarding the chosen drawing technique. This was followed by drawing (planning and implementation) and finally by question relating to satisfaction and eventual changes in drawing. It was specifically stressed that the students should include themselves in the drawing. The students were called person A, B and C, which was marked on the drawings and in the questionnaires. Their work was monitored by recording it with a video camera and the final drawings were photographed. 


\section{Results}

In the first stage, drawing of the human figure to the Nature Classes theme was monitored. These were pencil drawings.

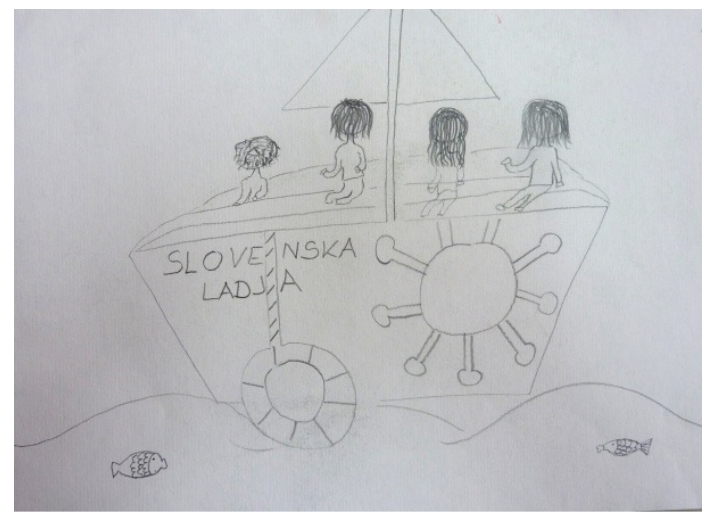

Drawing 1: Drawing by Girl A at Stage 1

Girl A began the process of drawing the human figure on the right side of the page. She first drew a circle for the head and covered the head with hair, i.e. she drew the head from behind. She drew the trunk and arms in movement (one sideways from the body and the other alongside the body) followed by legs in a sitting position. The feet of the figure are turned outwards. She drew three more figures to the left of the initial figure. The head of the next figure also faced away. She drew the hair, trunk and arms along the body. The figure was in a sitting position with the legs not fully visible. She used the same process in drawing two more figures in a sitting position and partially indicated movement. This girl drew from top to bottom (figure) and from right to left (the whole drawing). Other elements in the drawing included a ship, the sea (base line) and two fish facing each other.

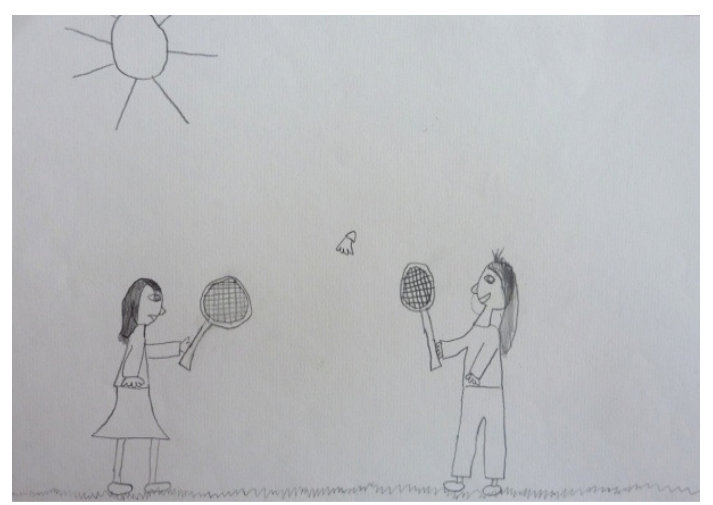

Drawing 2: Drawing by Girl B at Stage 1 
Girl B first drew a skirt on the left side of the page (bottom to top) followed by the trunk and an arm stretched out to the right. This arm held a badminton racket. She then drew the other arm alongside the body (across the trunk), the head from side view and the legs and feet turned towards the direction of the view. On the other side of the page, she drew, from bottom to top, trousers, the trunk with the left arm alongside the body and the right in the direction of the left figure and holding a racket. She proceeded with drawing the side view of the head so that the figures are facing each other and finally drew the feet. This girl drew from bottom to top (figure) and from left to right (the whole drawing). Other elements included in the drawing were a shuttlecock, grass (base line) and the sun.

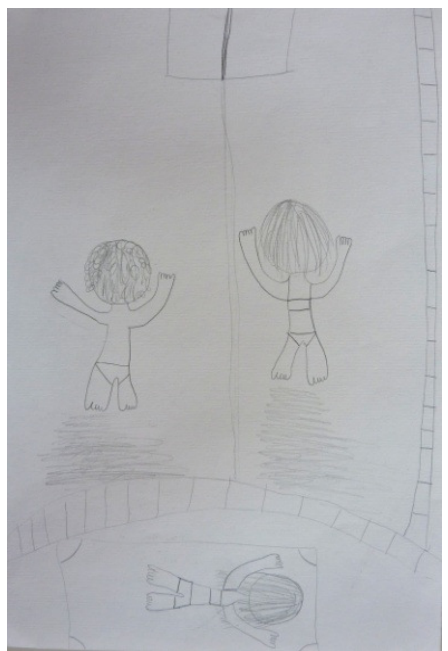

Drawing 3: Drawing by Girl C at Stage 1

Girl C drew the human figure by first drawing three circles as heads on the bottom and in the middle of the page (left and right). She used different lines to draw hair across these circles. The heads faced down. All figures were drawn from a bird's eye view. She continued by drawing the left figure. She drew the trunk from the neck down and arms turned upwards followed by the lower trunk, legs and a swimsuit in the position of a swimmer (dynamics). She drew the figure on the right from the back with arms stretched forward. She continued by drawing the lower trunk, legs, toes and a swimsuit (the figure is swimming). She drew the third figure (at the bottom of the page) employing the same process - trunk, arms, legs and the swimsuit (the figure is lying on a towel sunbathing). She indicated the gender of the figures with the swimsuits, as the girls (the figure on the right and the figure on the bottom of the page) are wearing a two piece swimsuit. Special details were the fingers and toes without specially marked feet and hands. This girl drew from top to bottom (figure) and from bottom to top (the whole drawing). Other elements 
included in the drawing were a swimming pool, a towel and a goal alongside the pool.

In the second stage, we monitored the drawing of a human figure employing the art technique of drawing with coloured pencils (coloured drawing) to the theme of Playing in the Playground.

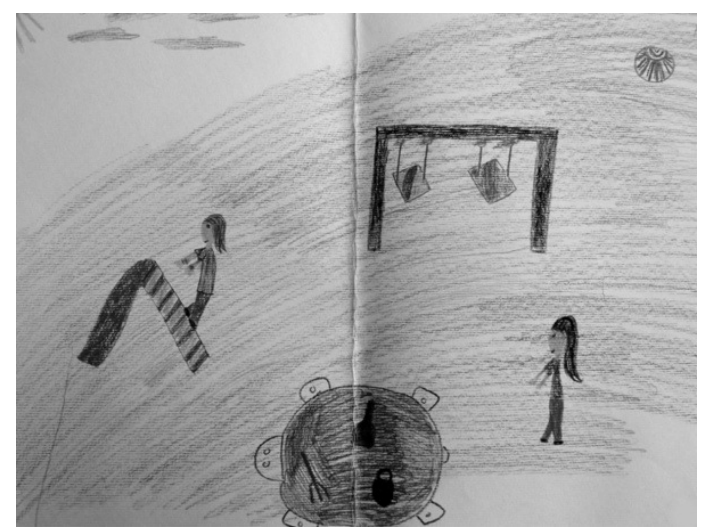

Drawing 4: Drawing by Girl A at Stage 2

Girl A began the process of drawing the human figure (coloured drawing) by drawing the first human figure on the left side of the page. She first drew the head from the side view, long hair (female) and continued by drawing the eyes, nose and mouth. She then drew the neck and the trunk and the arms turned to the left towards a slide. She drew the legs - first one and then the other which is partially lifted. The figure is depicted in movement while climbing a ladder. On the left side of the page, she drew another figure in the same way as the first. First the head from side view, long hair, eyes, nose, mouth, neck, trunk, arms turned to the left and then the legs. The legs are slightly apart indicating walking, i.e. movement. Other elements in the drawing include a slide, two swings, a turtle-shaped sandpit with toys (rake, shovel and bucket), a ball, the sun and clouds. The coloured pencils enabled her to express her emotions and to colour individual figures in the drawing. The girl drew from top to bottom (figure) and from left to right (the whole drawing).

Girl B began the process of drawing the human figure (coloured drawing) by first drawing a figure on the left side of the page. She began by drawing the trousers (legs) followed by the trunk and arms lifted upwards with palms and five fingers. She continued by drawing the neck and the head. She then drew the hair, eyes, nose and mouth and finally shoes (feet) turned to the right. She drew the next figure in the same way: legs, trunk with arms turned downwards, neck, head, hair, eyes, nose and mouth. She indicated the gender of the child with long hair and clothes. She concluded the figure by drawing the feet turned to the right. Approximately in the middle of the page, she drew two more figures in the same way; again a boy and a girl with arms turned downwards and feet turned to the left. This indicated two pairs standing opposite each other while playing with a ball. Other elements included in 
the drawing are a ball and a goal with a net. The coloured pencils enabled her to express her emotions and to colour individual figures in the drawing. The girl drew the figure from bottom to top and the whole drawing from left to right.

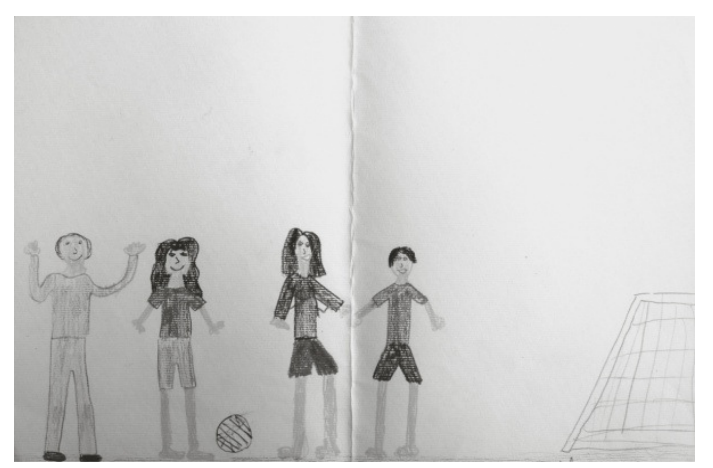

Drawing 5: Drawing by Girl B at Stage 2

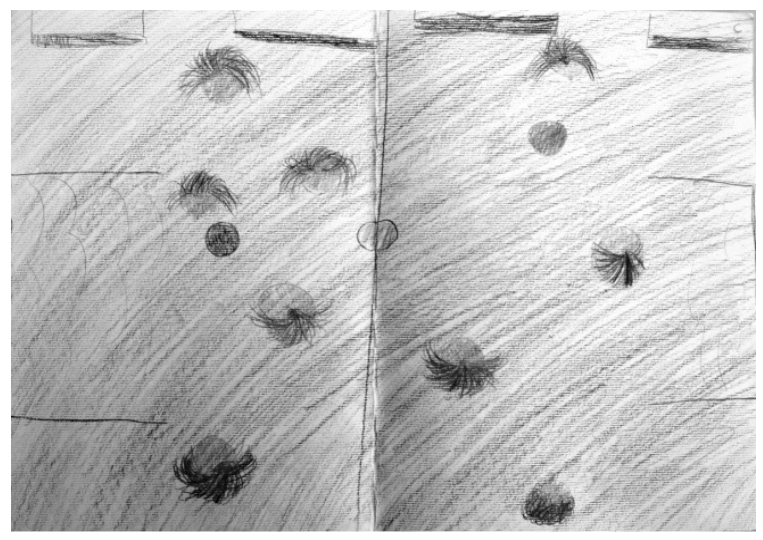

Drawing 6: Drawing by Girl C at Stage 2

Girl $\mathrm{C}$ began the process of drawing the human figure (coloured drawing) by first drawing nine circles for the head across the entire page. She drew four circles on the left and five circles on the right that she coloured yellow. She proceeded by drawing the hair. She drew the hair so that it is evident which way an individual figure is facing. She drew the nose in some of the figures, while other parts of the figures are not visible. Other elements included in the drawing are two balls and goals that she drew with two lines and indicated a net. She also drew the marks on the field. There are four brown horizontal elements in the foreground that represent benches for substitutes. The girl drew the figures from left to right (the whole drawing) in bird's eye view.

In the third stage, drawing of the human figure to the My Shadow theme was monitored. These were charcoal drawings. 


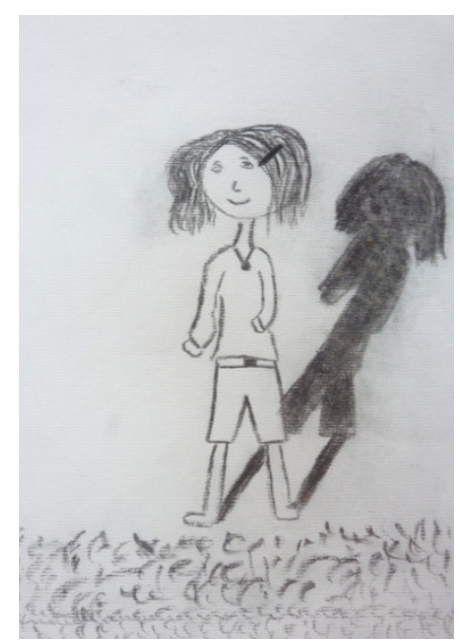

Drawing 7: Drawing by Girl A at Stage 3

Girl A began the process of drawing the human figure on the upper part of the page. She drew a circle for the head, hair on the left and right side of the head, eyes and eyebrows, the nose, mouth and finally a hairclip in the hair. This determined the figure's gender. She proceeded by drawing the neck, trunk, arms turned to the side (movement), trousers and legs with one foot turned right and the other left. In drawing the shadow, she used the reverse process and drew from the legs towards the head trying to keep the shape rather similar to the figure. She drew lines in different directions and with a different intensity thus drawing a grass surface at the bottom of the page.

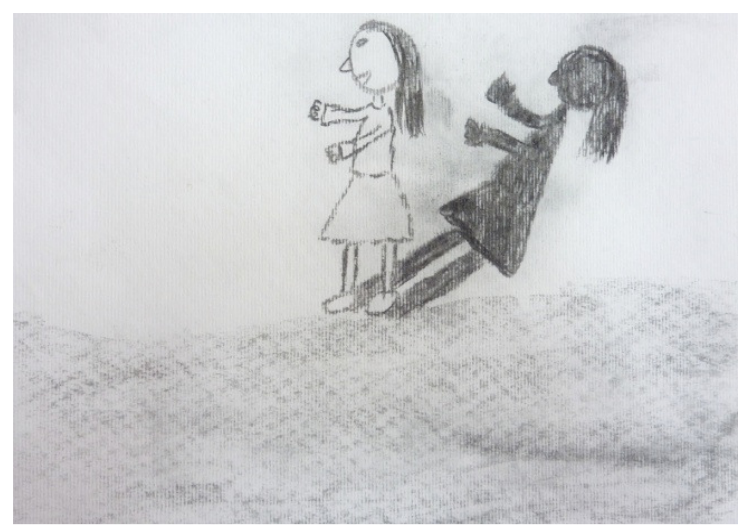

Drawing 8: Drawing by Girl B at Stage 3

Girl B began the process of drawing the human figure by first drawing a circle for the head on the upper part of the page. She added the hair on the right side followed by the nose on the left as well as the mouth, eye and neck. She then drew 
the arms turned to the left and the trunk. She continued by drawing the skirt, legs and feet that she turned to the left. She drew the face of the figure from side view and the lifted arms indicate her wish to depict movement. In drawing the shadow, she used the reverse process and drew from the legs towards the head trying to keep the shape of the shadow rather similar to the figure. She utilised the possibilities offered by this technique in intensifying the grey areas that she used to fill the foreground of the drawing.

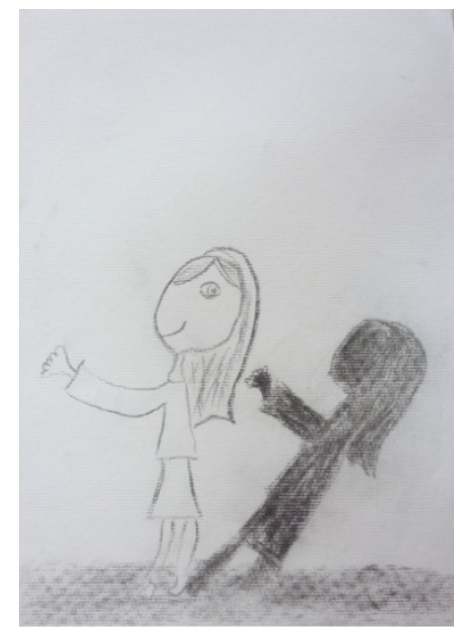

Drawing 9: Drawing by Girl C at Stage 3

Girl C drew the human figure by first drawing a circle for the head placing it on the upper part of the page. She then added long hair on the right side of the head and drew the eye in the middle and the mouth on the left. She drew the face from side view but did not draw the nose. Next she added the neck, trunk and one arm turned to the left depicting the hand and fingers. The skirt, legs and shoes followed. She drew the figure from side view turned to the left. She indicated gender by drawing a skirt and long hair and achieved the effect of movement with the outstretched arm. In drawing the shadow, she used the reverse process and drew from the legs towards the head trying to keep the shape rather similar to the figure. She utilised the possibilities offered by the technique of charcoal drawing in intensifying the grey areas in the foreground of the drawing.

\section{Discussion}

The analysis of products or photographs through all three stages shows certain characteristics that the girls displayed in depicting the human figure.

In all three stages, Girl A used the same process of depicting the human figure. She drew the figure from top to bottom starting with the head (hair, eyes, nose and mouth) and continuing with the neck, trunk, arms and legs in movement. 
She drew from side view and indicated movement. In the first two artworks, she chose the landscape orientation of the page and in the last the portrait orientation.

In the first two stages, Girl B used the same process in depicting the human figure, i.e. bottom to top. She first drew the trousers or skirt, trunk, arms and head (hair, eyes, nose and mouth) and finally the feet. She drew from side view and indicated movement. In the third stage, she began drawing from the head downwards. In all three drawings, she chose the landscape orientation of the page.

The same as Girl B, Girl C used the same process in depicting the human figure. She drew the figures in bird's eye view and began by drawing the head with the hair, while the nose, mouth and eyes are not visible. In the second stage, she drew the trunk, arms and legs after the head and indicated movement. In the third stage, she started by drawing the head from side view (hair, eye and mouth) and continued by drawing the trunk, arms, legs and feet. It is interesting that the girl chose the portrait orientation of the page in the first and third drawing and the landscape orientation only for the second drawing.

In the third stage, the process of drawing the human figure was identical, as all three girls drew the shadow in the opposite direction that the figure itself, i.e. from bottom to top (starting with the legs and moving towards the head). The influence of the drawing technique and the motif on the drawing process is evident (drawing with charcoal to the theme of My Shadow). In the first two stages, the art technique is identical as well as the process of drawing human figures employed by all three girls, which again indicates a certain connection of the art and design strategy with the art technique. It is evident that each of the girls has her own process of drawing the human figure. There was no influence of copying evident in the drawings. The girls created with self-initiative and with their own ideas and notions with regard to the determined theme. As regards their attitude to drawing and their artwork, there was a higher level of confidence and satisfaction with their own work present with Girls A and C, while Girl B did not express such a distinctive feeling of satisfaction with her creation. The provided answers and drawings indicate the level of mastery over drawing techniques and handling of different drawing material.

The photographs show a normal level of artistic development for all three girls. Girls A and B show a more realistic artistic expression that is characteristic of visual artistic types. Girl $\mathrm{C}$ on the other hand displays some imagination and can be regarded as a more imaginative type. As regards the design of their artwork, Girls A and $\mathrm{B}$ planned their artistic creation utilising visual memory, which indicates them to be more intellectual artistic types, while Girl $\mathrm{C}$ expressed herself more spontaneously, which is characteristic of expressive artistic types. From the viewpoint of affinity towards visual means of expression, Girl A and Girl B could be classified as constructive and decorative artistic types and Girl $\mathrm{C}$ as a more constructive and spatial artistic type, as she constructed her artwork in a well thought-out and steady disposition of art elements taking into consideration the optical space. As regards the art and design strategy and personal artistic factors, Girl A and Girl B can be classified as more analytical artistic types, as they derive 
from details that they combine into a unity. Girl $\mathrm{C}$ is a more synthetic artistic type, as she simplified her forms into a pure design as a whole. All three girls can be classified as motor and technical types, as they implemented their work with accuracy and skill.

The observations allow us to conclude that in drawing the human figure, the girls followed their own distinctly shaped art and design strategies. However, the influence of drawing techniques on the drawing process, which was especially evident in the third stage, cannot be neglected.

Summarising King's opinion (King et al. 1994), we can ascertain that in qualitative research, the study of more than one case mainly confirms the findings of causality thus giving them a higher generalisable value. The obtained results allow us to conclude that similar art and design strategies would be determined if monitoring a higher number of children. A similar research (Duh, 2009) used a case study to monitor art and design strategies of two preschool children and yielded identical results. The obtained results therefore allow us to develop the theory that given the same starting points, children will act, i.e. artistically create, with regard to their individual skills and characteristics and that in depicting the human figure they will employ their own characteristic process of depiction. The same is noted by Kircher saying that "Creative work does not only support the expansion of an individual's possibilities of expression but also the development of differentiated skills of perception and aesthetic sensibility as well as the ability of critical evaluation (Kircher et al., 2006:13,14). As regards direct arts education, this means that students should be encouraged to find their own way to realise the set artistic task. Only by developing a child's individuality in artistic expression can arts education yield creative results and encourage students to engage in their own artistic research.

\section{Bibliography}

Bryman A. (1996). Quantity and quality in social research. London:Loughborough. PEF.

Cencič M. (2002). Pisanje in predstavljanje rezultatov raziskovalnega dela. Ljubljana,

Cox M. (2005). The pictorial World of the child. Cambridge Univesity Press

Cugmas Z. (2003). Odraz socialnega vedenja otrok $z$ različnim vzorcem navezanosti na vzgojiteljico v otroški risbi. Psihološka obzorja, 12, 2, 49-63.

Duh M. (2009). Likovno-oblikovne strategije predškolske djece. Znanstvena monografija: Interdisciplinarni pristup učenju, put ka kvalitetnijem obrazovanju djeteta. UF Rjeka, PF Maribor, 85-97. Rokus.

Duh, M; Vrlič, T. (2003). Likovna vzgoja v prvi triadi devetletne osnovne šole. Ljubljana,

Duh, M. (2004). Vrednotenje kot didaktični problem pri likovni vzgoji. Maribor PEF.

Grgurič N., Jakubin M. (1996). Vizualno-likovni odgoj i obrazovanje. Zagreb: Educa.

Hodder, I. (2004). The Interpetation of Documents and Material Culture. V: Denzin, N.K.; Lincoln, Y. S. (ed). Methods in Development Research. Thousand Oaks London, Sage Publications, str 155-175. 
http://books.google.si/books?id=CdCGek5KJ_QC\&pg=PA155\&lpg=PA155\&dq=Hodder +The+Interpretation+of+documents+and+Material+Culture\&source=bl\&ots=RO0yFB9AD\&sig= byU6IefApmtSdvOua0Fzvzad50\&hl=sl\&ei=BJpsSsSaCYqQsAam34CQBw\&sa=X\&oi=book_res ult\&ct=result\&resnum $=2$

Karlavaris B., Kraguljac M. (1981).Razvijanje kreativnosti putem likovnog vspitanja u osnovnoj školi. Beograd, Prosveta.

Karlavaris B. (1991a). Metodika likovnog odgoja 1. Rijeka: Hofbauer p.o.

Karlavaris B. (1991b). Metodika likovnog odgoja 2. Rijeka: Hofbauer p.o.

King, G; Keohane, R. O; Verba, S. (2001). Designing Social Inquiry: Scientific Inference in Qualitative Research. Princeton University Press. (pridobljeno: 22.7.2009) http://press.princeton.edu/titles/5458.html

Kircher, C., Schiefer Ferrari, M., Spinner, K. H. (2006). Ästhetische Bildung und Identität. Fächerverbiendende Vorschläge für die Sekundarstufe I und II. München, Kopaed. 11.

Kukman K. (2007). Razumevanje otroškega likovnega jezika. EDUCA, letnik XVI, 4/5, 5-

Lichtman, M (2009). Qualitative Research in Education. A user's Guide. Edition 2. Thousand Oaks, London, Sage Publications.

Loizis P. (2003). Video, Film and Photographs as Research Documents. V: Bauer, M. W; Gaskell, G. (ed.) Qualitative Researching with Text, Image and Sound. A Practical handbook. London, Thousand Oaks, New Delhi: SAGE, str. 93-107. (pridobljeno 2.8.2009).

$\mathrm{http}: / / \mathrm{www}$. google.com/books?id=UQewQ4FzHowC\&printsec=frontcover\&hl=sl\#v=onep age $\& \mathrm{q}=\& \mathrm{f}=$ false

Marjanovič Umek L., Lešnik Musek P. (2001). Otroška risba. V: Marjanovič Umek L., Zupančič M. (2001). Razvojna psihologija: Izbrane teme. Ljubljana: Oddelek za psihologijo FF.

Mesec, B. (1998). Uvod v kvalitativno raziskovanje v socialnem delu. Ljubljana, VŠ zasocialno delo.

Muhovič J., Tomšič Čerkez B., Tacol T., Frelih Č., Špenko T., Kretič S., Prevodnik M., Duh M. (1999). Likovno snovanje: Priročnik za učitelje. Ljubljana: ZRSŠ.

O'Farrell, L; Meban, M (2005). Arts Education and Instrumental Outcomes:An Introduction to Research Methods. V: Meleisea E (ed.) Educating for Creativity: Bringing the Arts and Culture into Asian Education. Bangkok, UNESCO. Str. 115-124. (pridobljeno 3.8.2009) 09/21. pdf http://www.eric.ed.gov/ERICDocs/data/ericdocs2sql/content_storage_01/0000019b/80/28/

Peez, G. (2005). Evaluation ästhetischer Erfahrungs- und Bildungsprozesse. Beispiele zu ihrer empirischen erforschung. München; Kopaed.

Peez, G. (2006). Fotografien in pädagogischen Fallstudien. Sieben qualitativ-empirische Analyseverfahren zur ästhetischen Bildung - Theorie und Forschungspraxis. München; Kopaed.

Ragin, C. C. (2007). Družboslovno raziskovanje. Enotnost in raznolikost metode. Ljubljana, FDV.

Sagadin J. (1991b). Študija primera. Sodobna pedagogika, letnik 40, 9/10, 465-472.

Sagadin J. (1993). Kvalitativna analiza podatkov pri študiji primera. Sodobna pedagogika, letnik 44, 3/4, 115-123465-472.

Schrader, W. (2000). Die sinnerfüllte Kinderzeichnung von innen begriffen. Hohengehren, Schneider Verlag.

Vogrinec, J. (2008). Kvalitativno raziskovanje na pedagoškem področju. Ljubljana, Pedagoška fakulteta. Debora.

Vrlič T. (2001). Likovno-ustvarjalni razvoj otrok v predšolskem obdobju. Ljubljana,

Yin Robert, K. (1993). Applications of case study research. London: SAGE publications. 
Metodički obzori 7(2012)1

Izvorni znanstveni rad

UDK: 159.922.75:7.041]:373.3

Primljeno: 13. 10. 2010.

\section{INDIVIDUALNE POTI PRI SNOVANJU LIKOVNEGA DELA PRI UČENCIH OSNOVNE ŠOLE}

Dr. Matjaž Duh

Pedagoški fakultet, Universitet u Mariboru (Slovenia) e-mail: matjaz.duh@uni-mb.si

Aleksandra Slatinšek-Mlakar, prof. e-mail: sandrasm8@gmail.com

\section{Pov ze tek}

Članek obravnava raziskavo, v kateri smo spremljali postopek upodobitve človeške figure pri devetletnikih. Za raziskovanje smo uporabili študijo primera, kjer smo proučevali likovne izdelke treh deklic. Skozi kvalitativno raziskavo smo ugotavljali postopek risanja človeške figure na podlagi posnetkov z video kamero, fotografij in odgovorov na delovnih listih. Dobljene ugotovitve potrjujejo domnevo, da učenci izbirajo lastno, individualno pot pri gradnji likovnih del.

Ključne besede: risba, razvojne faze, postopek upodobitve, človeška figura.

\section{INDIVIDUALNI PUTEVI KOD GRAĐE LIKOVNOG RADA KOD DJECE OSNOVNE ŠKOLE}

\section{Sa žetak}

Članak prikazuje istraživanje u kojem smo pratili postupak prikaza čovjeka kod devetogodišnjaka. U istraživanju gdje smo proučavali likovne radove troje učenica primijenili smo studiju primjera. Kroz kvalitativno istraživanje utvrđivali smo postupak crtanja ljudskog lika na osnovi snimki video kamerom, fotografija i odgovora na radnim listovima. Dobiveni rezultati potvrđuju pretpostavku da učenice slijede vlastit, individualan put u građi likovnog rada.

Ključne riječi: crtež, razvojne faze, postupak likovne građe, ljudski lik, studija primjera. 